\title{
Which Values for Which Organization. Introduction to the Special Issue of the EBEN AC 2010 Conference
}

\author{
Michele Andreaus • Antonino Vaccaro • \\ Michael S. Aßländer
}

Published online: 26 November 2011

(C) Springer Science+Business Media B.V. 2011

The actual economic global slowdown poses many challenging issues to rethink about how CSR and business ethics can help in understanding the role of business organizations in the market, their purposes and their responsibility toward stakeholders and society at large. Since 2008 when the crisis broke out, academics, politicians and practitioners have tried to illustrate the main drivers of this slowdown. Even if a number of technical reasons related to economic and regulatory decisions have been identified, the abundant literature produced has emphasized the possibility that a lack of values lies at the core of the crisis and the amorality of business needs to be confronted.

There is now the broad consensus that the roots of the global crisis lie mainly in a lack of regulation control and policy coordination in the financial sector, and in the abuse of financial instruments leveraging short-term performance irrespective of the long run sustainability of the entire economic system. These are fundamentally macro-economic institutional issues. However, behind the economic causes, it is fairly easy to identify unethical actions and a lack of consideration of the social and ethical impact of economic and financial choices taken by business organizations and individual businessmen. In particular, from a business ethics perspective, the actual financial crisis has demonstrated that the mainstream neoclassical thinking, which is institutionalized both in economic theory and in

M. Andreaus

University of Trento, Trento, Italy

A. Vaccaro

IESE Business School, Barcelona, Spain

M. S. Aßländer

University of Kassel, Kassel, Germany business practice, could lead to abuses and misconduct since it underlines the conceptualization of market amorality and it views the firm as a nexus of contracts with the main purpose of maximizing the self-interested utility function of employees and shareholders.

Utilizing the abovementioned considerations for the 23rd Annual Conference of the European Business Ethics Network (EBEN) in Trento (Italy) from 9 to 11th September 2010, more than 200 researchers from around the world grappled with its challenging title-Which values for which organizations? Their aim was to discuss the role of business ethics in dealing with the ongoing financial slowdown and in preventing others, in particular by analyzing what role firms should have in the market, what their purposes should be and how values and moral concerns could be applied in managerial practices.

Since an economy and business organizations do not operate in a vacuum but are influenced by their cultural, social and political environment, companies and firms are affected by the established and taken-for-granted values, norms, and practices. To illustrate these aspects, the distinctive features of an Italian economic and social context were considered when defining the themes discussed in the conference as were the perspectives represented in this special conference-related issue.

Surprisingly the best and worst ethically and socially oriented practices coexist in Italy. On the one hand, Italy presents a prominent example of the struggles and threats that a lack of values and ethics in business organizations and the market can lead to. The famous Parmalat scandal, the number of bribery and corruption cases, and the influence of the mafia criminal organization in many economic sectors are all constrains which hinder the economic, social and political growth, not only of some geographical areas, but of the entire country. These instances provide clear 
evidence of the dangerous implications that greed, lack of values and moral commitment, and a dearth of concern for the common good of society and the wellbeing of all the organizational stakeholders can cause.

On the other hand, however, Italy upholds numerous business practices which are firmly established in strong ethical values - the social enterprise movement or the so-called civil economy and the many small and medium sized, as well as family owned, enterprises which have never considered wealth creation for shareholders as being the only duty of a business organization. Instead, they also understand their responsibilities in terms of the quality of employment conditions, social and environmental value creation and ethical concerns, thus going beyond shortterm solutions by trying to create wealth in a sustainable and ethically oriented manner. Moreover, Italian business studies has historically proposed a managerial approach based on the centrality of human beings, and has asserted the ethical dimension of every economic and business decision by proposing that business organizations should be set up to achieve a complex system of wellbeing involving not only the economic and financial dimensions, but also the social, cultural, and relational aspects.

Given these premises, while selecting papers for this special issue of the Journal of Business Ethics we tried to best represent the work of the conference but also to bring together those papers that illustrate how ethics, moral thinking, and values can be operationalized at individual and organizational level. This special issue contains eight papers.

The first is the paper by our keynote speaker, Thomas Donaldson, who deals with the ethical causes of the actual economic crisis by identifying three patterns-paying for peril, the normalization of questionable behavior and techshock - which have led financial institutions and business leaders to commit unethical behaviors. Thomas Donaldson examines the implications of each of these ethical roots of the crisis, highlighting the fact that these risk factors have a more significant impact at the industry rather than firm level. Accordingly he argues that regulation cannot be a complete solution to this crisis and therefore calls for a new form of industry-level cooperative responsibilities based on the sake of the health of the industry and of society in general.

The second and third articles, written, respectively, by Dorothea Baur and Hans Peter Schmitz and Antonino Vaccaro, deal with ethical issues related to managerial and accountability practices in not for profit organizations. In their conceptual paper, Dorothea Baur and Hans Peter Schmitz focus on the risk of co-optation that NGOs face when collaborating with for profit organizations. The authors argue that the increased commercialization of NGO practices, the greater ties which exist between for profit and not for profit organizations, the strategic understanding of Corporate Social Responsibility, and the need for more accountability from NGOs could lead to a loss of autonomy thus reducing their legitimacy as societal watchdogs. According to the authors, increased collaboration with for profit organizations could eventually divert NGO attention from other stakeholders and decrease their responsiveness to the needs of their beneficiaries. The authors argue that a political understanding of Corporate Social Responsibility may help in dealing with these challenges because this would blur the boundaries between for profit and not for profit organizations and would enhance a corporation's capacity to solve social problems while achieving a sustainable competitive advantage.

Antonino Vaccaro also discusses the social sector. However, his research is empirical in nature since it aims at investigating the legitimacy and ethical implications of transparency practices in a successful Italian anti-racket NGO-Addiopizzo. In his longitudinal micro-level case study, Antonino Vaccaro investigates how Addiopizzo leverages information disclosure as a strategy against social resistance to change and to acquire legitimacy, or rather moral legitimacy in an adverse environment. The author's findings provide empirical insights into the ethical principles inspiring the people who are fighting the mafia, and the importance of information transparency in struggling against the environmental socio-economical conditions that foster the survival and growth of corrupted and unethical organizations.

The article by Iain Davies, Zoe Lee and Ine Ahonkhai is an exploratory study rooted in the ethical consumption research stream. The authors investigate whether there are differences between convenience good shoppers and luxury good shoppers by analyzing consumer preferences from structured interviews collected via a quota sample of 199 UK consumers on the main shopping streets of two cities in the UK. The results of the study point out that ethical conditions of production are significantly less important in luxury purchase decisions than in commodities because prestige, self-image, and convenience are all more important than ethics in the priority buying criteria for luxury goods. For these reasons, the authors conclude that even if there is a ready market for ethical luxury products, this would be smaller than the markets currently available to commodity type products.

The fifth article of Hoje Jo and Maretno Harjoto titled "The Causal Effect of Corporate Governance on Corporate Social Responsibility" presents an empirical investigation of the correlation and the mutual effects of corporate governance, corporate social responsibility, and social performance. In their study, based on a broad sample of US-based companies, the authors found correlation between companies' corporate social responsibility engagement and the 
financial performance of the firms. Furthermore, the authors show that corporate governance structures have positive influence on CSR which supports the authors' hypothesis that CSR functions as an extension of effective CG mechanisms to resolve conflicts between managers and noninvesting stakeholders.

The sixth article written by Björn Fasterling is a conceptual study. The idea is that a compliance disclosure regime may be more helpful in developing business norms than as an alternative mechanism for social regulation. Specifically, it is argued that compliance disclosure could be a starting point for the development of norms by enabling explicit dialogue about the application of norm proposals and their interpretation involving companies and stakeholders. This dialogue may eventually have beneficial effects in the development of norms, in particular with regard to contexts in which the existence of norms is uncertain or their use is under discussion.

The last two articles are both conceptual papers which interpret business organizations as a community of persons and try to reconcile economic and moral arguments in a more humanistic manner.

Domenec Melè challenges the classical understanding of business organizations as abstract entities where conflicting stakeholder interests are balanced. Instead, he fosters an idea of business organizations as a human community of persons, discussing the axiological and managerial implications of this view. Accordingly, the author emphasizes the fact that a business as a community of persons entails considering the uniqueness and dignity of each person as well as fostering commitment toward the common good of society. This challenges managers to change their commonly accepted role of being the builder of systems, structures, and strategy to becoming the facilitator for the development of people within the community.

Finally, Ericka Costa and Tommaso Ramus present a study which reconciles economic and moral arguments by linking Catholic Social Teaching with the Italian Management School, the so-called Economia Aziendale. Their work points out that understanding business organizations as a community of persons to contribute to the societal common good may be helpful in identifying the existing similarities and differences between for profit and not for profit organizations and in narrowing the ephemeral dichotomy between economic and moral ends.

As Editors and on behalf of the EBEN Executive Committee, we would like to take this opportunity to thank all the colleagues who agreed to serve as anonymous reviewers for this special issue and all the participants who came to Trento from around the world and made the conference a success. Our final appreciation goes to the invaluable Organizing Committee. 